\section{Reassess-Realign-Reimagine: A Guide for Mentors Pivoting to Remote Research Mentoring}

\author{
Christine Pfund, ${ }^{\text {t** Janet L. Branchaw, }}{ }^{\S}$ Melissa McDaniels, ${ }^{*}$ \\ Angela Byars-Winston," Steven P. Lee", and Bruce Birren" \\ ${ }^{\dagger}$ Institute for Clinical and Translational Research and \#Wisconsin Center for Education Research, \\ University of Wisconsin-Madison, Madison, WI 53705; 'Wisconsin Institute for Science Education \\ and Community Engagement and Department of Kinesiology, University of Wisconsin-Madison, \\ Madison, WI 53706; "Department of Medicine, Center for Women's Health Research, University of \\ Wisconsin-Madison, Madison, WI 53715; "School of Humanities and Sciences, Stanford University, \\ Stanford, CA 94305; and \#Broad Institute of MIT and Harvard, Cambridge, MA 02142
}

\begin{abstract}
Maintaining your research team's productivity during the COVID-19 era can be a challenge. Developing new strategies to mentor your research trainees in remote work environments will not only support research productivity and progress toward degree, but also help to keep your mentees' academic and research careers on track. We describe a three-step process grounded in reflective practice that research mentors and mentees can use together to reassess, realign, and reimagine their mentoring relationships to enhance their effectiveness, both in the current circumstances and for the future. Drawing on evidence-based approaches, a series of questions for mentees around documented mentoring competencies provide structure for remote mentoring plans. Special consideration is given to how these plans must address the psychosocial needs and diverse backgrounds of mentors and mentees in the unique conditions that require remote interactions.
\end{abstract}

\section{INTRODUCTION}

An unprecedented situation requiring remote research mentorship from faculty and research group leaders has emerged from the COVID-19 health crisis. In spring 2020, active laboratories and research centers were suddenly required to close, and many universities were forced to suspend nearly all research-related operations. By fall 2020, many universities began operating virtually, and many research relationships pivoted to remote engagement. Consequently, progress toward degree completion and research productivity has been negatively impacted, and tens of thousands of undergraduate, graduate, and postdoctoral research mentees have been engaging with their mentors remotely. Even as laboratories and research centers have reopened, there are guidelines for social distancing that extend the impact of the pandemic in terms of research activities and research mentoring relationships. The relevance of remote mentoring extends well beyond the current health crisis. In fact, remote mentoring has been a reality for many trainees and their mentors for years-for example, data-collection trips, conference attendance, sabbatical leave, and personal relocation. The intensity and length of the COVID-19 health crisis has provided an opportunity for mentors and trainees to be more intentional about adjusting their mentoring practices to accommodate changes in proximity and the resulting shift in the mode and frequency of their meetings.

The ability of mentors to pivot and adopt new ways to lead their research teams during disruptions like a pandemic is a critical factor in fostering talent development and maintaining research productivity. In this Essay, we apply the metacognitive concept of reflective practice to remote research mentoring relationships and offer
Derek Braun, Monitoring Editor Submitted Jul 14, 2020; Revised Dec 14, 2020; Accepted Dec 30, 2020

CBE Life Sci Educ March 1, 2021 20:es2 DOI:10.1187/cbe.20-07-0147

*Address correspondence to: Christine Pfund (cepfund@wisc.edu).

(c) 2021 C. Pfund et al. CBE-Life Sciences Education () 2021 The American Society for Cell Biology. This article is distributed by The American Society for Cell Biology under license from the author(s). It is available to the public under an Attribution-Noncommercial-Share Alike 3.0 Unported Creative Commons License (http://creativecommons.org/licenses/ by-nc-sa/3.0).

"ASCB®" and "The American Society for Cell Biology $\circledR^{\prime \prime}$ are registered trademarks of The American Society for Cell Biology. 
strategies to help mentors build positive relationships that keep mentee learning and development on track and maintain research productivity in remote working environments and other exceptional circumstances.

\section{CONCEPTUAL BACKGROUND}

Following Schon's (1983) original articulation of the reflective practitioner, Eraut (1995) clarified that reflective practice occurs in three distinct time frames: 1) "in action" while applying one's practice; 2) "on action" after one's practice takes place; and 3) "for action," considering how one can develop one's practice in the future. In any organization, including a research team, leaders need to be nimble and adjust the ways they look at problems, address challenges, and carry out their work, particularly in times of institutional change (Bollman and Deal, 2013). As research team leaders and mentors navigate changing professional environments, they must be able to reframe their practices (Schon,1983), reimagine actions that were previously routine, and consider how new circumstances demand different ways of working. Reflective practice is vital to providing effective leadership and mentoring in complex, evolving research environments like the one created by COVID-19.

\section{REMOTE RESEARCH MENTORING: REFLECTIVE PRACTICE}

Remote mentoring refers to developmental relationships at a distance that can be sustained using a combination of synchronous technology (those technologies that promote communication between individuals at a specific point in time, e.g., telephone, electronic chat, videoconferencing) and asynchronous tools (those tools that promote communication and do not require scheduling that communication at a specific point in time, e.g., email, analogue mail/shipping) to nurture the mentoring relationship. Remote mentoring can be easily conflated with e-mentoring, as e-mentoring relationships (Bierema and Merriam, 2002) also occur at a distance, independent of a specific point in time, and rely upon asynchronous tools. However, these relationships differ in that they are intentionally designed to take place within asynchronous electronic spaces and primarily involve knowledge transfer (Rowland, 2012). The authors of this paper are using the term "remote mentoring" to refer to sustained working alliances that would typically operate as in-person relationships, but due to unforeseen circumstances like the COVID-19 pandemic, are operating in synchronous and asynchronous online spaces. In these forced remote mentoring relationships occurring in times of crisis, mentors must devote particular focus to psychosocial and professional support of their mentees and themselves (National Academies of Sciences, Engineering, and Medicine [NASEM], 2019).

The involuntary, unplanned, remote, and socially distanced research mentoring that has been forced by the current pandemic required many research mentors and mentees to quickly pivot to engage with one another in new ways. This is similar to the situation described for emergency remote teaching (Hodges et al., 2020), in which the abrupt change and uncertain duration of a complex, evolving situation can cause physical stress, mental stress, and anxiety, all of which can be further exacerbated by variable access to the technical and professional resources needed to support teaching (or mentoring) in remote work environments.
Working in complex, evolving crisis conditions add to the heightened stress experienced by both mentors and mentees. Before the COVID-19 pandemic, there was a growing mental health crisis for undergraduate and graduate students reporting anxiety, depression, suicidal ideation, and self-harm, with students' use of university counseling centers increasing an average of 30-40\% from 2009 to 2015 (Evans et al., 2018; Center for Collegiate Mental Health, 2019). The stress stemming from social isolation, family members getting sick, fear of the unknown future, and other factors during the pandemic has exacerbated trainees' mental health concerns (Huckins et al., 2020). Consequently, increased attention to psychosocial practices in mentoring relationships that facilitate mental, emotional, and physical well-being is needed.

Kram (1985) stated that psychosocial mentoring positively contributes to mentees' sense of identity, competence and effectiveness in their professional roles and can take the form of role-modeling, conveying unconditional positive regard and affirmation, attending to mentees' values, and providing emotional support by discussing mentees' concerns and assisting them with problem solving (NASEM, 2019). Mentors need not necessarily implement solutions for their mentees' mental health concerns, but they should actively inquire about their mentees' mental state and be prepared to refer them to professional resources like college counseling services or the Crisis Text Line (see Table 1) or to evidence-based practices, such as mindfulness practice, which has recently been found to improve doctoral students' mental health (Barry et al., 2019). Additionally, Cooper et al. (2020a) outlined recommendations for promoting an inclusive research experience for students with depression, and the National Institutes of Health Office of Intramural Training and Education (NIH OITE) curates a wellness resource website (see Table 1), both of which mentors may find useful in supporting their students. Although some mentors may be uncomfortable or unfamiliar dealing with these psychosocial issues, it is important that they be considered and addressed during a crisis like the COVID-19 pandemic.

\section{REMOTE RESEARCH MENTORING: MAKING THE MOST OF IT}

Despite the challenges of life during a pandemic and a forced sudden shift to remote mentoring, it is an opportunity to reflect on mentoring approaches and to rethink strategies to improve mentorship. As Rahm Emanuel has said, "Never let a serious crisis go to waste." Past research has documented the benefits of remote work such as increased flexibility in schedules, lack of commute time, and more time with family both in academia and outside academia (Buffer, 2020; Meiners, 2020). It has been shown that individuals whose work requires significant problem solving, like researchers' work, may actually be more effective due to fewer distractions and more satisfied when working remotely (Golden and Gajendran, 2019). As such, incorporation of structures (e.g., online video meetings, shared online documents) and strategies (e.g., more frequent checkins, explicit goal setting) to support effective remote mentorship has the potential to lead to more functional in-person mentoring relationships in general.

Mentors should be reflective practitioners by leveraging the known benefits of remote work whenever possible. As reflective practitioners, mentors should also leverage the evidence base 
TABLE 1. Questions for mentees and mentoring tools and strategies to transition to strong remote mentoring relationships

\begin{tabular}{|c|c|c|}
\hline 1. Reassess & 2. Realign & 3. Reimagine \\
\hline \multicolumn{3}{|l|}{ Maintaining effective communication } \\
\hline $\begin{array}{l}\text { What aspects of our in-person communication } \\
\text { were working well for you? (What aspects } \\
\text { were not working well?) }\end{array}$ & $\begin{array}{l}\text { What communication strategies would you } \\
\text { like to continue to use remotely and what } \\
\text { new strategies would you like to try? }\end{array}$ & $\begin{array}{l}\text { How would you prefer to communicate } \\
\text { remotely? } \\
\text { - frequency } \\
\text { - } \text { synchronous/asynchronous } \\
\text { - } \quad \text { response times }\end{array}$ \\
\hline \multicolumn{3}{|c|}{$\begin{array}{l}\text { Mentoring tools and strategies: regularly scheduled synchronous online meetings with shared agendas; communication style inventories; practicing active listening } \\
\text { when online; agreeing on preferred ways to connect with a quick question such as a Skype or Slack message or a text }\end{array}$} \\
\hline \multicolumn{3}{|l|}{ Aligning expectations } \\
\hline $\begin{array}{l}\text { What were your research and professional } \\
\text { priorities before moving to remote work? } \\
\text { How were you tracking progress on your } \\
\text { priorities? }\end{array}$ & $\begin{array}{l}\text { What adjustments should we consider making } \\
\text { to these priorities as a result of the shift to } \\
\text { remote work? Have any new needs or } \\
\text { realities arisen? }\end{array}$ & $\begin{array}{l}\text { How would you like to track progress on your } \\
\text { priorities in a remote working environ- } \\
\text { ment? Are there any online tools we could } \\
\text { use to facilitate tracking remotely? }\end{array}$ \\
\hline
\end{tabular}

Mentoring tools and strategies: mentor-mentee compacts/written plans; scheduled accountability check-ins to reaffirm shared expectations; regular progress reports on remote work

\section{Assessing understanding}

How did you prefer to ask questions and/or confirm your understanding about research and your training experience before we began to work remotely?
In what ways would you prefer to ask questions and/or confirm your understanding about research and your training experience in the remote environment?
What new tools might we use to ask/answer questions and share perspectives in the remote environment?

Mentoring tools and strategies: online running documents to share questions and answers; instant-messaging tools; a shared commitment to respond to inquiries in a timely manner

\begin{tabular}{|c|c|c|}
\hline \multicolumn{3}{|l|}{ Addressing equity and inclusion } \\
\hline $\begin{array}{l}\text { What did I do in person that supported your } \\
\text { connections and collaborations with our } \\
\text { research group? What helps you feel a } \\
\text { sense of belonging with our research group } \\
\text { or gets in the way of this? }\end{array}$ & $\begin{array}{l}\text { How can I help you to stay connected to me } \\
\text { and to the research group in a remote } \\
\text { working environment? Do you have any } \\
\text { circumstances that may make this } \\
\text { challenging? }\end{array}$ & $\begin{array}{l}\text { In what new ways could I facilitate our } \\
\text { remote research group interactions to } \\
\text { ensure everyone engages and feels } \\
\text { welcome? What new tools or strategies } \\
\text { could we use to stay connected? }\end{array}$ \\
\hline \multicolumn{3}{|c|}{$\begin{array}{l}\text { Mentoring tools and strategies: regular wellness checks with individual mentees; accommodating individual mentee needs when scheduling online research grour } \\
\text { meetings; provide opportunities for students to talk about their experiences }\end{array}$} \\
\hline \multicolumn{3}{|l|}{ Fostering independence } \\
\hline $\begin{array}{l}\text { To what extent were you comfortable with the } \\
\text { degree of independence you had working } \\
\text { on your research when we were working in } \\
\text { person? }\end{array}$ & $\begin{array}{l}\text { Would you like more or less independence in } \\
\text { making and carrying out decisions about } \\
\text { your project in the remote work } \\
\text { environment? }\end{array}$ & $\begin{array}{l}\text { How can I provide the support and oversight } \\
\text { you need to make progress on your } \\
\text { research project in a remote working } \\
\text { environment? }\end{array}$ \\
\hline
\end{tabular}

Mentoring tools and strategies: individual development plans; regular progress reports on remote work; online task management tools

\section{Promoting professional development}

How clear were your career goals and the timelines for achieving those goals before we began working remotely? What were you doing in person that supported progress toward these goals?
How has working remotely impacted your career goals, the timeline for achieving them, or your ability to engage in activities to make progress toward them?
What can I and/or our research group do to support your career goals and professional development remotely? Is there anything in particular you are worrying about with respect to your future?

Mentoring tools and strategies: individual development plans; mentoring network maps; provide opportunities to discuss the uncertainties of the current and future job market

Additional resources:

Mentoring in a Time of Crisis and Uncertainty

Mentoring in Crisis Does Not Need to Put Mentorship in Crisis: Realigning Expectations

Mentoring during the COVID-19 Pandemic

Lab Work under Isolation

For Many Graduate Students, Covid-19 Pandemic Highlights Inequities

Mindful Mentorship

NIH Office of Intramural Training and Education-Wellness Resources

American Psychological Association COVID-19 Information and Resources

Crisis Text Line: free 24/7 support (in the United States, Canada, United Kingdom) 
on effective mentoring, including the empirically informed mentoring competencies that are known to contribute to quality research mentoring relationships (for a review, see NASEM, 2019). Specifically, we invite research mentors to use the threestep reflective process outlined here to develop mentoring practices that are responsive to their mentees' needs.

\section{OPTIMIZING REMOTE RESEARCH MENTORSHIP: REASSESS-REALIGN-REIMAGINE}

Effective mentoring behaviors are critical to the development of research mentees, and core mentoring principles in the fields of science, technology, engineering, mathematics, and medicine have been tested and collated (NASEM, 2019). The three-step process proposed here overlays the lens of a reflective practitioner on these evidence-based mentoring competencies and provides questions (Table 1) to guide research mentors' professional reflection to develop remote research mentoring plans in collaboration with their research mentees. Importantly, every mentor-mentee relationship is unique. Therefore, there are no "right" answers to the questions posed in Table 1. Instead, mentors must focus on asking probing questions, actively listening to their mentees' answers, and adjusting their mentoring approach in reflective ways.

Beyond existing relationships that have been forced to pivot to a remote environment, mentors must also be prepared to build new mentoring relationships under remote conditions when the circumstances require it. Though new mentoring relationships have not had the benefit of an established foundation from in-person interactions, faculty mentors and mentees may still benefit from this three-step reframing process, because they likely have preconceived notions about how a "normal" or ideal in-person mentoring relationship should operate.

As new remote mentoring relationships began, mentors and mentees needed to focus on the first two principles of effective mentoring relationships-communication and expectations-because they form the foundation for the other principles. Additionally, as they work remotely and if social gatherings are restricted, mentors and mentees need to be more attentive to fostering a sense of connection within the dyad. They do not have the opportunity to see each other through either planned or coincidental meetings in the office, the lab, or the hallway. Thus, connections and communication are decreased. Moreover, the lack of proximity can make it easier to be nonresponsive, ignore emails, or simply focus on only what is right in front of us. Intentional time to connect and communicate is critical, and specifically building in time at the beginning of each meeting to ask how your mentees are feeling can be helpful. Finally, if the mentoring dyad operates within the context of a research group, it is essential to intentionally introduce activities that build community among peers, such as those that help mentors and mentees recognize and capitalize on differences and enhance cross-group friendships among peers (Page-Gould et al., 2008).

\section{Step 1: Reassess}

Engage your mentee in a conversation around the questions in Table 1 . This is an opportunity to discuss attributes of the mentoring relationship that may not have been previously addressed between the two of you or that need to be revisited in a remote working environment and in the current context. These questions can be provided to mentees to reflect upon and respond to asynchronously before a conversation.

\section{Step 2: Realign}

Based on your conversation in step 1, collaborate with your mentee to articulate shared goals for maintaining aspects of the mentoring relationship that are going well and improving those that are not, paying particular attention to each of your needs in the current context.

\section{Step 3: Reimagine}

Develop a mutually agreed upon plan to achieve these goals in your remote work together. Schedule regular check-in meetings to revisit the plan and make changes if necessary. Plans that are successful should persist beyond the current crisis.

We note that the needs of mentees differ across career stages. The framework described here can be revisited and revised to meet each mentee's contextual and evolving needs. Specific mentoring tools and approaches for each competency (Handelsman et al., 2005; Pfund et al., 2006, 2014, 2015) are listed in Table 1; many of the tools are also available in the National Academies online guide to the Science of Effective Mentorship in STEMM (www.nap.edu/resource/25568/interactive).

\section{SELF-CARE AND CARING FOR YOUR MENTEES DURING A CRISIS}

Because crisis conditions can precipitate or exacerbate emotional distress, mentors may also experience personal and professional stressors and anxieties while still needing to support their mentees. These stressors may inhibit them from being the kind of mentor that they want to be. Thus, while mentors attend to their mentees' academic and career development, they must also attend to their own wellness. Some questions to consider when tending to their own or their mentees' wellness include: "Do I/you have a positive strategy(ies) to handle stress?"; "How might I support my/your self-care during this time?"; "Do I/you have at least one practice that brings meaning to my/your day, week, or month?"; "What support resources are available to me/you (e.g., local campus, national)?" Resources such as those available from the NIH OITE noted in the table can be helpful in this regard. Importantly, mentees may be uncomfortable sharing that they are struggling with anxiety or other mental health issues. Because mental health can be a concealable stigmatized identity, it can be hard for mentors to provide support (Cooper et al., 2020b). To provide students opportunities to address these needs, mentors may want to offer students the chance to take personal days without specifying the need.

\section{FOCUSING ON WHAT MATTERS THE MOST: THE RELATIONSHIP}

What matters most in remote mentoring, as in face-to-face mentoring, is the relationship itself (NASEM, 2019; Hernandez et al., 2017). Whether working remotely or in person, it is important that mentors prioritize attending to the well-being and humanity of their mentees as they facilitate their research and professional development. This component of mentorship may not be foremost on the minds of either mentors or mentees, who may instead be focused on the lack of research progress 
resulting from limited access to laboratory space, colleagues, and other critical resources. Further, reduced progress toward research goals and the absence of anticipated results to support, for example, grant applications or degree completion, combined with the threats from situations like the COVID-19 pandemic may contribute to a heightened sense of vulnerability. Given these circumstances, it is particularly important that mentors explicitly discuss with mentees their expectations around research productivity in times of crisis. For example, mentors should regularly discuss with mentees what constitutes realistic expectations for the mentees' use of time and revise these as needed, along with any new views of what it means to "be productive" in a crisis. In some cases, mentors may want to emphasize aspects of professional development that are often starved for time, such as making progress on the skills and experiences reflected in students' individual development plans or helping mentees review and strengthen their mentoring and support networks (Branchaw et al., 2020).

Inviting research mentees to examine and share their psychosocial needs when developing remote mentorship plans is particularly important (Eby et al., 2013). If mentors do not invite mentees to share their psychosocial needs and reassure them that these needs are important, mentees may feel uncomfortable sharing the difficulties they are experiencing due to the power dynamics of the relationship, a lack of trust in the relationship, or for fear that their concerns could be interpreted as excuses. For example, mentees may be overwhelmed by the volume of electronic communication they are receiving, the lack of structure to guide their work, or slower progress than expected through transitions in career stages. Broader adaptations and concerns related to the crisis and other social forces may be interfering with students' ability to work or concentrate. For example, mentees may be experiencing financial uncertainty, too much or too little contact with families, new caregiving responsibilities for household members who are being schooled at home, they may be ill or suddenly unemployed, or they might be questioning their desire to continue research given the challenges that underlie chronic underrepresentation of those with similar social identities. Without knowledge of the kinds of psychosocial challenges their mentees are facing, mentors may unknowingly develop remote mentorship plans that actually inhibit their mentee's research productivity, development, and academic persistence.

In the pivot from in-person to remote mentoring, understanding a mentee's psychosocial needs is especially important for mentees with whom mentors may not have had a strong connection in person (Blake-Beard et al., 2011). The needs and responses of mentees will vary widely, so actively inviting all mentees to share their psychosocial needs will help ensure that mentors are attuned to their mentees across social and cultural groups, not just those from similar backgrounds, or who are most vocal or self-initiating. Furthermore, active listening by the mentor in conversations with mentees is especially important, because mentees' lived experiences outside the lab may be unfamiliar to and offer different challenges than mentors experience. In sum, we encourage mentors to be intentional in cultivating the human and empathic parts of their mentoring relationships with all their mentees (Gotian, 2020), which includes not only feeling concern and perspective taking but a willingness to act in addressing their needs.

\section{CONCLUSION}

Advancing your research agenda in extreme circumstances like a pandemic requires creativity, flexibility, and regular communication with your research team members, especially those who are in training and rely on your mentorship to guide their learning and development. Be kind, do not make assumptions, ask questions, actively listen to the answers, and offer understanding and flexibility. Take advantage of the opportunity that a remote working environment presents to be a reflective practitioner and to reassess, realign, and reimagine your research mentoring relationships. The structures mentors create now to ensure productive interactions with research mentees and their progress on research projects, while regularly acknowledging the importance of psychosocial well-being, is likely to yield lasting benefits, including more effective mentoring relationships with those mentees and higher research productivity in the future.

\section{ACKNOWLEDGMENTS}

We thank Rick McGee, Pam Asquith, Stephanie House, and Sonia Zarate for their insightful feedback on this article. We also thank the following for their support of the authors: the University of Wisconsin-Madison (UW-Madison) Departments of Kinesiology (J.L.B.) and Medicine (A.B.-W.); the Howard Hughes Medical Institute (GT11808; B.B., C.P., A.B.-W.); the National Institutes of Health National Human Genome Research Institute to the Broad Institute (HG006682; B.B.) and National Center for Advancing Translational Sciences to the UW-Madison (UL1TR002373-01; C.P.).

\section{REFERENCES}

Barry, K., Woods, M., Martin, A., Stirling, C., \& Warnecke, E. (2019). A randomized controlled trial of the effects of mindfulness practice on doctoral candidate psychological status, Journal of American College Health, 67(4), 299-307

Bierema, L. L., \& Merriam, S. B. (2002). E-mentoring: Using computer mediated communication to enhance the mentoring process. Innovative Higher Education, 26, 211-227.

Blake-Beard, S., Bayne, M. L., Crosby, F. J., \& Muller, C. B. (2011). Matching by race and gender in mentoring relationships: Keeping our eyes on the prize. Journal of Social Issues, 67(3), 622-643.

Bollman, L. G., \& Deal, T. E. (2013). Reframing organizations: Artistry, choice, and leadership. San Francisco, CA: Jossey-Bass

Branchaw, J. L., Butz, A. R., \& Smith, A. R. (2020). Entering research: A curriculum to support undergraduate and graduate research trainees (2nd ed.). New York, NY: Macmillan.

Buffer. (2020, April). State of remote work report. Retrieved April 30, 2020 from https://buffer.com/state-of-remote-work-2019\#

Cameron, K., Daniels, L., Traw, E., \& McGee, R. (2020). Mentoring in crisis does not need to put mentorship in crisis: Realigning expectations. Journal of Clinical and Translational Science, 1-2. https://doi:10.1017/ cts.2020.508.

Center for Collegiate Mental Health. (2019). 2018 Annual Report (Publication no. STA 19-180). University Park: Pennsylvania State University, Center for Collegiate Mental Health

Chopra, V., \& Saint, S. (2020). Mindful mentorship. Healthcare, 8(1), 100390.

Cooper, K. M., Gin, L. E., Barnes, M. E., \& Brownell, S. E. (2020a). An exploratory study of students with depression in undergraduate research experiences. CBE-Life Sciences Education, 19(2), ar19.

Cooper, K. M., Gin, L. E., \& Brownell, S. E. (2020b). Depression as a concealable stigmatized identity: What influences whether students conceal or reveal their depression in undergraduate research experiences? International Journal of STEM education, 7(1), 27.

Eby, L. T., Allen, T. D., Hoffman, B. J., Baranik, L. E., Sauer, J. B., Baldwin, S., ... \& Evans, S. C. (2013). An interdisciplinary meta-analysis of the potential 
antecedents, correlates, and consequences of protégé perceptions of mentoring. Psychological Bulletin, 139(2), 441-476.

Eraut, M. (1995). Schon shock: A case for refraining reflection-in-action? Teachers and Teaching, 1(1), 9-22.

Evans, T. M., Bira, L., Gastelum, J. B., Weiss, L. T., \& Vanderford, N. L. (2018). Evidence for a mental health crisis in graduate education. Nature Biotechnology, 36(3), 282.

Gotian, R. (2020, April 3). Mentoring during the COVID-19 pandemic. Nature Careers Community. https://doi.org/10.1038/d41586-020-01028-x

Golden, T. D., \& Gajendran, R. S. (2019). Unpacking the role of a telecommuter's job in their performance: Examining job complexity, problem solving, interdependence, and social support. Journal of Business Psychology, 34, 55-69.

Handelsman, J. C. P., Lauffer, S. M., \& Pribbenow, C. M. (2005). Entering mentoring: A seminar to train a new generation of scientists. Madison, WI: University of Wisconsin Press

Hernandez, P. R., Estrada, M., Woodcock, A., \& Schultz, P. W. (2017). Mentor qualities that matter: The importance of perceived (not demographic) similarity. Journal of Experimental Education, 85(3), 450-468.

Hodges, C., Moore, S., Lockee, B., Trust, T., \& Bond, A. (2020). The difference between emergency remote teaching and online learning. Educause Review. Retrieved March 29, 2020, from https://er.educause.edu/ articles/2020/3/the-difference-between-emergency-remote-teaching -and-online-learning

Huckins, J. F., DaSilva, A. W., Wang, W., Hedlund, E., Rogers, C., Nepal, S. K., .. \& Campbell, A. T. (2020). Mental health and behavior of college students during the early phases of the COVID-19 pandemic: Longitudinal smartphone and ecological momentary assessment study. Journal of Medical Internet Research, 22(6), e20185.

Kram, K. E. (1985). Mentoring at work: Developmental relationships in organizational life. Glenview, IL: Scott Foresman.

Meiners, J. (2020, February). Why and how you should let your postdocs work remotely. Chronicle of Higher Education. Retrieved February 15, 2020, from http://chronicle.com

National Academies of Sciences, Engineering, and Medicine. (2019). The science of effective mentorship in STEMM. Washington, DC: National Academies Press.

Page-Gould, E., Mendoza-Denton, R., \& Tropp, L. R. (2008). With a little help from my cross-group friend: Reducing anxiety in intergroup contexts through cross-group friendship. Journal of Personality and Social Psychology, 95(5), 1080-1094.

Pfund, C., Branchaw, J. L., \& Handelsman, J. (2015). Entering mentoring. (2nd ed.). New York: Freeman.

Pfund, C., House, S. C., Asquith, P., Fleming, M. F., Buhr, K. A., Burnham, E. L., ... \& Sorkness, C. A. (2014). Training mentors of clinical and translational research scholars: A randomized controlled trial. Academic Medicine 89(5), 774-782

Pfund, C., Maidl Pribbenow, C., Branchaw, J., Miller Lauffer, S., \& Handelsman, J. (2006). The merits of training mentors. Science, 311(5760), 473-474.

Rowland, K. N. (2012). E-mentoring: An innovative twist to traditional mentoring. Journal of Technology Management \& Innovation, 7(1), 228237. https://dx.doi.org/10.4067/S0718-27242012000100015

Schon, D. A. (1983). The reflective practitioner: How professionals think in action. New York: Basic Books. 